UDC 347.921

DOI https://doi.org/10.32849/2663-5313/2021.9.03

Serhii Koroied,

Doctor of Law, Professor, Professor at the Department of Law, King Danylo University, 35, Yevhen

Konovalets street, Ivano-Frankivsk, Ukraine, postal code 76018, KoroedSerhii@ukr.net

ORCID: orcid.org/0000-0002-1833-3149

Koroied, Serhii (2021). Procedural effects of filing a lawsuit against an affiliate of a legal entity in civil proceedings. Entrepreneurship, Economy and Law, 9, 18-22, doi: https://doi.org/10.32849/ 2663-5313/2021.9.03

\title{
PROCEDURAL EFFECTS OF FILING A LAWSUIT AGAINST AN AFFILIATE OF A LEGAL ENTITY IN CIVIL PROCEEDINGS
}

Abstract. The purpose of the article is to determine the procedural consequences of filing a lawsuit against a branch office of a legal entity in civil proceedings. Results. The article continues to explore new aspects of the problem of improper defendant in civil proceedings. An example is a case in which the Supreme Court formulated the procedural effects of filing a lawsuit against an affiliate that is not a legal entity. Based on the analysis of court practice and theoretical provisions of civil proceedings, the possibility of applying replacement of an improper defendant in connection with filing a lawsuit against affiliate or representative office that is not a legal entity is studied. The definition of "improper defendant" in civil proceedings is revealed, as well as the connection of the parties with the parties to the disputed pecuniary legal relations. It is put forward the case law approach according to which filing a lawsuit against an improper defendant is a ground for rejecting to satisfy the lawsuit against such improper defendant. It is concluded that this approach provides for the existence of a civil proceeding that began and ended with respect to an "improper" defendant. The impossibility of the existence of a civil process with the participation of subjects who do not have civil locus standi, in terms of the lawsuit theory, an element of which the author calls the parties. Conclusions. Since the parties (along with the ground and the subject matter) are defined as elements of the lawsuit, the lawsuit cannot exist without the party (plaintiff or defendant). In this regard, it is argued that in the case of filing a lawsuit against an entity that does not have civil locus standi, the procedural institution of replacement of an improper defendant cannot be applied. At the same time, it is substantiated that if at the time of opening the proceedings there is a legal entity - the defendant, but it was incorrectly identified, then there are no grounds for rejecting to open proceedings. It is proposed to provide a mechanism for "determining the correct name of the legal entity - the defendant", referring to the tasks of the court at the stage of preparatory proceedings.

Key words: improper defendant, civil locus standi, legal entity, affiliate, lawsuit, termination of proceedings, civil case, civil proceedings.

\section{Introduction}

In terms of scientific publications, the author has already addressed the problem of the improper defendant in civil proceedings and considered it an obstacle to the effective judicial protection of the violated rights of the plaintiff, justifying the need to restore procedural powers to the courts (rights and, at the same time, duties) to replace, on their own initiative, the original, that is, improper defendant by the proper defendant (if the action is brought against a person other than the one to be sued) or additionally involve another person as co-defendant (in case of mandatory procedural complicity on the part of the defendant) (Koroed, 2018).

The issue (that is, the issue of an improper defendant) takes on a new meaning in the light of the recent decision of the Supreme Court composed of the Joint Chamber of the Civil Court of Cassation in civil case 760/32455/19, which has considered the procedural effects of filing a lawsuit against an affiliate, while it is not a legal person, and has examined the question of refusal of a lawsuit on grounds of improper parties. In this case, the Supreme Court has concluded that cases in which the defendant is an affiliate or representative office are not subject to civil proceedings because there is no party sued to the civil proceedings, and, consequently, a civil dispute cannot be resolved (Judgment of the Supreme Court of the Joint Chamber of the Civil Court of Cassation, 2021)

Therefore, the option of applying replacement of an improper defendant in connection 
with filing a lawsuit against an affiliate or representative office that is not a legal person is primarily of scientific and practical interest. The aim of the article is to consider this issue on the basis of the analysis of judicial practice and theoretical provisions of civil procedure.

2. Features and definition of an improper defendant in civil proceedings

An improper defendant in civil proceedings is defined by procedural law scholars as a person established by the court to be not a probable actor of the legal obligations subject to the court judgement, and, in this connection, subject to replacement or a court decision on rejecting the lawsuit (Bychkova, 2010, p. 77). The Supreme Court defines an improper defendant as a person who has been sued by the plaintiff as a defendant established as not to be sued when there is evidence that another person is under an obligation to comply with the plaintiff's demands: proper defendant (Resolution of the Supreme Court composed of the panel of judges of the Third Judicial Chamber of the Civil Court of Cassation, 2020).

According to part 2 of art. 51 of the Civil Procedure Code of Ukraine, if an action is brought against a person other than the person to be sued, the court before the preparatory proceedings is completed, and in the case of a simplified action, before the opening hearing, at the request of the plaintiff, replaces the original defendant with the proper defendant, without closing the proceedings.

In other words, under this procedural provision, one defendant is replaced with another defendant with the status of proper one. In previous publications, the author has already established that the defendant must be a party to and materially concerned in the contentious pecuniary (civil, family, housing, labour, land, etc.) legal relationship with the plaintiff. It is precisely on such grounds that a defendant in civil proceedings is found "proper" (that is, the person to be sued) and it is in respect of such defendant that the lawsuit can be satisfied, that is, that the plaintiff has been provided with the remedy of his rights violated (realization of the objective of civil proceedings) (Koroed, 2018, p. 93).

On the basis of the provisions of, inter alia, civil law, housing law and labour law, the parties to these pecuniary legal relations are natural persons (employers, employees) and legal entities (executive committees of local councils, enterprises and organizations, employers). Moreover, this approach is reflected in the provisions of Civil Procedure Code of Ukraine, referring to defendants as to parties to civil proceedings (part 1, art. 48), and the parties as to participants in a case (part 1, art. 42), who have rights and obligations (art. 43). The ability to have civil procedural rights and obligations, as well as the potential to be a participant in a case in general, is determined by the civil locus standi that all natural and legal persons have (part 1, art. 46). With regard to the parties (as participants in the case), the Civil Procedure Code of Ukraine further stipulates that the plaintiff and the defendant may be natural and legal persons, as well as the State (part 2, art. 48).

\section{Features of judicial practice}

The court practice has long developed the approach that an action against an improper defendant is a ground for denving the lawsuit against such an improper defendant. For example, the Supreme Court, in a number of decisions, has taken the legal position that the defendant is an obligatory participant in a civil proceeding, the party to it. The main feature of the parties to a civil proceeding is their personal and direct interest; it is the parties that are the subjects of the legal relations over which the dispute has arisen. In addition, the defendant is the person whom the claimant identifies as infringer of his right. An improper defendant is a person sued by the plaintiff as a defendant but established to be not sued when there is evidence that another person, the proper defendant, is under an obligation to comply with the plaintiff's demands. Under part 4 of article 263 of the Civil Procedure Code of Ukraine, when selecting and applying the provision of law to contentious legal relations, the court takes into account the conclusions on applying the relevant provisions of law set out in the decisions of the Supreme Court. It is the right of the plaintiff to determine the defendants, the subject matter and the grounds of the dispute. On the other hand, it is the duty of the court to establish the identity of the defendants and the validity of the lawsuit in the case. That is, bringing an action against an improper defendant is an autonomous ground for rejecting a lawsuit (Resolution of the Supreme Court of the panel of judges of the Third Judicial Chamber of the Civil Court of Cassation, 2021). The Grand Chamber of the Supreme Court supports this approach, concluding that an action against an improper defendant does not constitute a ground for rejecting to open proceedings, since the replacement of an improper defendant is carried out in the manner prescribed by the Civil Procedure Code of Ukraine. On the basis of the results of the case consideration, the court refuses the lawsuit against the improper defendant and decides on the merits of the lawsuit of the proper defendant. That is, it is the right of the plaintiff to determine the defendants, the subject matter 
and the grounds for the dispute. On the other hand, it is the duty of the court to determine whether the defendants are proper and the reasonableness of the lawsuit, and this duty is to be fulfilled during consideration of the case not at the commencement of the proceedings (Resolution of the Grand Chamber of the Supreme Court, 2018). Having found that the action has been brought against an improper defendant and that there are no specific procedural grounds for replacing an improper defendant with a proper defendant, the court dismisses the action against such defendant (Resolution of the Grand Chamber of the Supreme Court, 2020).

Therefore, this approach assumes the existence of a civil proceeding which has started and ended with an "improper" defendant. At the same time, the conclusion by the Supreme Court composed of the Joint Chamber of the Court of Cassation in the case $760 / 32455 / 19$ generally denies the existence of a civil proceeding (action), which identifies an entity (such as an affiliate) that has no legal personality and therefore no civil capacity, as the defendant.

In our view, however, this position of the Supreme Court could be reinforced by other arguments. For example, it is well known that the parties (such as the plaintiff and the defendant), together with the ground and the subject matter, individualize lawsuit, which is of not only a theoretical but also of a practical significance in determining the identity or difference of the lawsuit with others. In civil procedure law, there is a rule on the inadmissibility of a second presentation and examination of a lawsuit that is identical with a lawsuit that has already been accepted by another court, or that has an enforceable judicial decision. The identification of the subject matter and the ground for an action helps the defendant determine what the claimant requires of him and on what grounds. Finally, knowing what the subject and ground of the action are, enables to establish the limits of court consideration correctly (Isaenkova, 1997, pp. 69-70). Since a lawsuit is a procedural means of initiating proceedings, the parties (as an element of the lawsuit) must therefore have the proper status of a natural or legal person, as defined by law. After all, just as a dead natural person cannot be a defendant in a civil proceeding, an organization without legal personality (or liquidated legal entity) cannot be a participant in a case. And since the parties (along with the ground and the subject matter) are defined as elements of the lawsuit, without the party (plaintiff or defendant), the lawsuit cannot exist.
That is, in the event of an action brought against a subject without civil locus standi, and the procedural replacement of an improper defendant (art. 51 of the Civil Procedure Code of Ukraine) cannot be applied. In practice, however, lawsuits by plaintiffs against dead natural persons (when, for example, the plaintiff is not aware of the death of the defendant, a natural person) or affiliates of legal persons (or liquidated or reorganized legal entities) are not excluded. In such cases, there can be no procedural succession, since under art. 55 of the Civil Procedure Code of Ukraine, the participation in the case of the successor of the party concerned or of a third party at any stage of the proceedings is possible if the death of a natural person or the termination of a legal person have occurred after the opening of the proceedings.

The Supreme Court, composed of a panel of judges of the First Trial Chamber of the Court of Cassation in case 676/5955/18-c, has agreed with the conclusion of the Court of Appeal on the of annulment of the decision of the District Court and the termination of the proceedings, since the plaintiff brought an action against an affiliate of the enterprise, which under Article 95 of the Civil Code of Ukraine is not a legal person, and therefore does not have civil locus standi, and therefore cannot be a party to civil proceedings, while noting that the Court of Appeal, by virtue of its procedural powers under the Civil Procedure Code of Ukraine of Ukraine, has been deprived of the possibility to bring a proper defendant before the court of cassation, as well as no such procedural possibility exists for the court of cassation (Resolution of the Supreme Court composed of the panel of judges of the First Judicial Chamber of the Civil Court of Cassation, 2019).

At the same time, in one of the cases challenging disciplinary sanctions, in which a court clerk brought an action against the head of the Chervonozavodsk District Court of Kharkiv, the Supreme Court of Ukraine noted that the lawsuits derive from labour law relations in which the district court is one of the parties. The very fact that the Chervonozavodsk District Court was not indicated in the statement of lawsuit by the defendant could not be a ground for denying it (Ruling of the Judicial Board for Civil Cases of the Supreme Court of Ukraine, 2020). We argue that this approach is more appropriate in ensuring accessibility of justice as a component of the right to go to court. Moreover, it is the task of the court at the stage of the preparatory proceedings, which begins with the opening of proceedings in the case, to make a final determination of the participants in the trial (para. 1 
of part 1 and part 2 of art. 189 of the Civil Procedure Code of Ukraine).

In our opinion, therefore, this case cannot apply the resolution by the Grand Chamber of the Supreme Court that the provision "an application shall not be subject to civil proceedings" applies both to lawsuits that are not subject to civil proceedings and to lawsuits that are not subject to court consideration at all (Resolution of the Grand Chamber of the Supreme Court, 2018). Indeed, in our case, the "proper" defendant with civil locus standi existed in law and in fact at the time of the commencement of the proceedings, but the name of the defendant was incorrectly stated (that is, the name of the affiliate was erroneously stated instead of the name of the legal person itself) in the application by the plaintiff, who was legally ignorant Therefore, in this case (case 760/32455/19 on recovery at work), it cannot be said that such a lawsuit was "not subject to a civil proceeding" or "could not be subject to court consideration at all." Consequently, we argue that this excludes the possibility of implementing para. 1 of part 1 of art. 186 (a judge rejects commencement of proceedings if the application is not subject to civil proceedings) or para. 1 of part 1 of art. 255 (the court dismisses the proceeding by the ruling if the case is not subject to civil proceedings).

4. Conclusions

In view of this, the author argues that article 51 of the Civil Procedure Code of Ukraine should provide for the mechanism of "definition of the correct name of the legal entity, the defendant", referring this to the tasks of the court at the preparatory stage. Thus, when the defendant is identified as a legal entity with civil locus standi, there will be procedural grounds for deciding on the replacement of an improper defendant (if the plaintiff disagrees with the court's determination of the correct name of the legal entity, the defendant). The author believes that this will enhance both the efficiency of civil proceedings in general and the guarantees of accessibility to civil justice.

\section{References:}

Bychkova, S.S. (2010). Vyznachennia nenalezhnoi storony u tsyvilnomu protsesi Ukrainy [Definition of the improper party in the civil process of Ukraine]. Forum prava - Forum of Law, 4, 75-80 (in Ukrainian).

Isaenkova, O.V. (1997). Isk v grazhdanskom sudoproizvodstve: Uchebnoye posobiye [Claim in civil proceedings]. Saratov: SGAP (in Russian).

Koroed, S.O. (2018). Problema nenalezhnoho vidpovidacha u tsyvilnomu sudochynstvi iak pereshkoda efektyvnomu sudovomu zakhystu prav pozyvacha. [The problem of improper defendant in civil proceedings as an obstacle to effective judicial protection of the rights of the plaintiff]. Sudova apeliatsiia - Court Appeal, 2 (51), 91-100 (in Ukrainian).

Postanova Velykoyi Palaty Verkhovnoho Sudu vid 01 kvitnya 2020 roku v spravi № 520/13067/17 [Resolution of the Grand Chamber of the Supreme Court of 1 April 2020 in case 520/13067/17]. (2020). court.gov.ua. Retrieved from https://reyestr.court.gov.ua/Review/89251545 (in Ukrainian).

Postanova Velykoyi Palaty Verkhovnoho Sudu vid 17 kvitnya 2018 roku u spravi № 523/9076/16-ts [Resolution of the Grand Chamber of the Supreme Court of April 17, 2018 in case 523/9076/16-ts]. (2018). court.gov.ua. Retrieved from https://reyestr.court.gov.ua/ Review/73469613 (in Ukrainian).

Postanova Velykoyi Palaty Verkhovnoho Sudu vid 21 lystopada 2018 roku u spravi № 757/43355/16-ts. [Resolution of the Grand Chamber of the Supreme Court of November 21, 2018 in case 757/43355/16-ts]. (2018). court.goz.ua. Retrieved from https://reyestr.court.gov.ua/ Review/78977475 (in Ukrainian).

Postanova Verkhovnoho Sudu u skladi kolehii suddiv Tretoi sudovoi palaty Kasatsiinoho tsyvilnoho sudu vid 7 zhovtnya 2020 roku v spravi № 705/3876/18. [Resolution of the Supreme Court composed of the panel of judges of the Third Judicial Chamber of the Civil Court of Cassation of October 7, 2020 in case 705/3876/18]. (2020). court.goz.ua. Retrieved from https://reyestr.court. gov.ua/Review/92120313 (in Ukrainian).

Postanova Verkhovnoho Sudu u skladi kolehiyi suddiv Pershoyi sudovoyi palaty Kasatsiynoho tsyvil'noho sudu vid 22 travnya 2019 roku v spravi № 676/5955/18-ts. [Resolution of the Supreme Court composed of the panel of judges of the First Judicial Chamber of the Civil Court of Cassation of May 22, 2019 in case 676/5955/18-ts]. (2019). court.goz.ua. Retrieved from https://reyestr.court. gov.ua/Review/82420332 (in Ukrainian).

Postanova Verkhovnoho Sudu u skladi kolehiyi suddiv Tret'oyi sudovoyi palaty Kasatsiynoho tsyvil'noho sudu vid 12 kvitnya 2021 roku v spravi № 557/94/19. [Resolution of the Supreme Court of the panel of judges of the Third Judicial Chamber of the Civil Court of Cassation of 12 April 
2021 in case 557/94/19]. (2021). court.goz.ua. Retrieved from https://reyestr.court.gov.ua/ Review/96179645 (in Ukrainian).

Postanova Verkhovnoho Sudu u skladi Obiednanoi palaty Kasatsiynoho tsyvil'noho sudu vid 14 chervnya 2021 roku v spravi № 760/32455/19. [Judgment of the Supreme Court of the Joint Chamber of the Civil Court of Cassation of 14 June 2021 in case 760/32455/19]. (2021). court.gov. ua. Retrieved from https://reyestr.court.gov.ua/Review/97771626_(in Ukrainian).

Ukhvala sudovoyi kolehiyi $\mathbf{v}$ tsyvil'nykh spravakh Verkhovnoho Sudu Ukrayiny vid 29.11.2000. Rishennya Verkhovnoho Sudu Ukrayiny [Ruling of the Judicial Board for Civil Cases of the Supreme Court of Ukraine of 29 November 2000. Decision of the Supreme Court of Ukraine]. (2020). court.gov.ua. Retrieved from https://www.viaduk.net/clients/vs.nsf/0/F631CFC15396726CC2256C5600408D8D?OpenDocument (in Ukrainian).

\section{Сергій Короєд,}

доктор юридичних наук, доцент, професор кафедри права, ЗВО «Університет Короля Данила», вулиия Свгена Коновальия, 35, Івано-Франківськ, Україна, індекс 76018, KoroedSerhii@ukr.net

ORCID: orcid.org/0000-0002-1833-3149

\section{ПРОЦЕСУАЛЬНІ НАСЛІДКИ ПРЕД'ЯВЛЕННЯ ПОЗОВУ ДО ФІЛІЇ ЮРИДИЧНОЇ ОСОБИ В ЦИВІЛЬНОМУ СУДОЧИНСТВІ}

Анотація. Метою статті є визначення процесуальних наслідків пред'явлення позову до філії юридичної особи в цивільному судочинстві. Результати. У статті продовжується дослідження нових аспектів проблеми неналежного відповідача в цивільному судочинстві. Як приклад розглядається справа, у якій Верховний Суд сформулював процесуальні наслідки пред'явлення позову до філії, яка не є юридичною особою. На основі аналізу судової практики та теоретичних положень цивільного процесу досліджено можливість застосування інституту заміни неналежного відповідача у зв’язку з пред’явленням позову до філії чи представництва, які не є юридичною особою. Розкривається визначення поняття «неналежний відповідач» у цивільному процесі, а також з'ясовується зв'язок сторін з учасниками спірних матеріальних правовідносин. Наводиться вироблений судовою практикою підхід, згідно з яким пред'явлення позову до неналежного відповідача є підставою для відмови в задоволенні позову щодо такого неналежного відповідача. Робиться висновок, що зазначений підхід передбачає існування цивільного процесу, який розпочався та завершився щодо «неналежного» відповідача. Обгрунтовується неможливість існування цивільного процесу за участю суб'єктів, які не володіють цивільною процесуальною правоздатністю, з позиції теорії позову, елементом якого названо сторони. Висновки. Встановлено, що оскільки сторони (поряд із підставою та предметом) визначаються як елементи позову, то без сторони (позивача або відповідача) позов існувати не може. У зв'язку із цим аргументовано, що у випадку пред’явлення позову до суб'єкта, не наділеного цивільною процесуальною правоздатністю, процесуальний інститут заміни неналежного відповідача не може застосовуватися. Водночас констатовано, що якщо на момент відкриття провадження у справі юридична особа - відповідач існує, проте їі було неправильно визначено, то підстави для відмови у відкритті провадження у справі відсутні. Пропонується передбачити механізм визначення правильного найменування юридичної особи - відповідача шляхом віднесення цього до завдань суду на стадії підготовчого провадження.

Ключові слова: неналежний відповідач, цивільна процесуальна правоздатність, юридична особа, філія, позов, закриття провадження, цивільна справа, цивільне судочинство.

The article was submitted 15.09.2021

The article was revised 06.10.2021

The article was accepted 27.10.2021 